\title{
THE ESOTERIC NATURE OF DEATH PREPARATIONS IN TAOISM AND THEIR POSSIBLE SOURCES
}

\begin{abstract}
A b s tract. Stephen Eskildsen has analysed a corpus of texts belonging to the Taoist tradition of internal alchemy, paying special attention to near-death meditations. Taking Eskildsen's conclusions as the starting point, the main purpose of this paper is to show the similarities between death preparation techniques in Taoism ("entering the womb", "changing the dwelling place" and "repelling killer demons") and the esoteric practices of Tibetan Buddhism (The Six Yogas of Nāropa). The subject was chosen, firstly, because some of them were omitted by Eskildsen, and secondly because those similarities seem to be interesting in the context of establishing the possible sources of Taoist meditations. An attempt at analysing the origins of both sets of practices, and the relationships between them, led to the conclusion that the influence of Indian esoteric ideas on Chinese Taoism is highly probable. The author also noted that the breathing exercises that constitute the basis of all of the techniques in question are prior Buddhist influences, and thus the independent development of these practices is also possible. Such independent development may be considered interesting, as both Chinese and Tibetan techniques are based on a similar notion of mystical physiology, which subsequently could suggest some kind of universality.
\end{abstract}

Key words: esoteric practices; internal alchemy; death preparation techniques; intermediate state; Taoism; Yungdrung Bön; Six Yogas of Nāropa.

\section{INTRODUCTION}

Stephen Eskildsen in his "Emergency Death Meditation for Internal Alchemists" (373-409) analysed two very interesting texts from Tang dynasty (618-907 CE) belonging to Taoist tradition of internal alchemy. ${ }^{1}$ The

Ewa PAŚNIK-TuŁowIECKA, PhD - University of Warsaw, Faculty of Oriental Studies, Department of Sinology; e-mail: ewa.pasnik@uw.edu.pl. ORCID: https:// orcid.org/0000-0003-0679$350 \mathrm{X}$.

${ }^{1}$ Chin. neidan 内丹 also known as inner elixir or internal alchemy; a Taoist practice which combines theories and practices of external alchemy (making immortality elixirs from minerals, metals, rare plants), metaphysics of Book of Changes (Yijing 易经), breathing, gymnastics and 
texts describe meditation techniques for prolonging one's life at the moment of death. If an internal alchemist during his/her natural lifespan failed to develop properly his/her inner spirit ${ }^{2}$, and thus couldn't achieve immortality, he/she could use these practices to gain some additional time to become Taoist transcendent. ${ }^{3}$ These texts are Taibai huandan pian 《太白还丹篇》 (The Taibai Return to the Cinnabar Field) and Zhen longhu jiushen jing 《真 龙虎九仙经》(The Book of the Real Dragon-Tiger Union of Nine Transcendents). In the article mentioned above, Eskildsen presented both the texts in detail, discussed their status and uniqueness in Taoist religious literature, and partially translated them into English. He also noticed some similarities between the Chinese Taoist ideas and Tibetan esoteric Buddhism, especially the idea of remaining in control of oneself after the moment of death in so called "intermediate state," (Tib. bar do; Sanskr.: antarabhāva; Chin. 中有 zhongyou or 中陰 zhongyin) and influencing one's future incarnation. Eskildsen also tried to point the sources of practices in question and finally concluded that they are "associated with both indigenous and Indo-Buddhist conception of death and the afterlife" (404). Eskildsen made quite detailed comparison between visions one can experience in Tibetan bardo and in Taoist intermediate state and suggested that the notion of controlling its outcome was either a simultaneous development in both traditions, or a Taoist influence on Tibetan esoteric Buddhism (385-386).

Taking Eskildsen's reflections and conclusions as the starting point, the main purpose of this paper is to present other similarities between Taoist near death meditations and Tibetan esoteric practices such phowa (Tib. 'pho ba, Sanskr. utkrānti) or tummo (Tib. gtum-mo, Sanskr. candālī) and to discuss relationship between them. Because the key point is to show general simila-

meditation techniques to achieve immortality or the state of union with the Dao. For further details see The Encyclopedia of Taoism 762-766.

${ }^{2}$ Chin. shen 神 is, according to Chinese medicine and Taoist philosophy, the most refined of three kinds of energies that can be found in human body. The other two are: "essence" (jing 精) and "pneuma" or "breath" ( $q i$ 气). Essence is the most "material" energy that comes from food and nourishes five main organs in human body. "Pneuma" is between essence and spirit. It is a dynamic force of human organism. Refining one into another through practice (essence into pneuma and pneuma into spirit) is a very important concept of internal alchemy. For further details see The Encyclopedia of Taoism 562-565 entry: jing, qi, shen by Catherine Despeux.

${ }^{3}$ Chin. 仙(人) xian(ren) often translated as "immortal." According to Miura Kunio, the original graph (僊) meant ascend, transfer oneself into heaven using wings. At the beginning the transcendents were imagined as inhabitants of paradise - a place which was very hard or impossible to find and get to (island or high, steep mountain). They were free from death, ageing and diseases. Over time the idea of transcendents became more and more elaborated. See The Encyclopedia of Taoism 1093-1094, entry: xianren by Miura Kunio. See also Campany. 
rities between the techniques themselves, without any textual comparison or detailed linguistic analyses, the use of English translation of the Tibetan text can be justified. ${ }^{4}$ Detailed textual study on both sets of practices, especially in the context of "mystical physiology" could be the next step in the research on timeline relationship between Taoist and esoteric Buddhist practices.

Phowa, bardo and tummo are present in Buddhist traditions of Tibet but also in Yungdrung Bön (Tib. g.yung drung bon)-pre-Buddhist religious tradition of Tibet. However, it is Six Yogas of Näropa or Six Dharmas of Näropa (Tib. na ro chos druk) that seem to be the oldest source where they appear together as a set of teachings extracted from different Tantras. The compilation is traditionally attributed to Nāropa (956-1041) - Indian monk and later a disciple of Tilopa (988-1069), from whom he was supposed to receive transmission for this set of practices. According to the legendary accounts, at the beginning the teachings existed in the oral form and were supposed to be passed in the whispered tradition from mouth of a teacher directly to the ear of a disciple for thirteen generations of masters and disciples. The line of whispered transmission starts from Nāropa, who passed those teachings to Marpa Chökyi Lodrö (Tib.mar pa chos-kyi blo-gros), also known as Marpa Lotsāwa (1012-1097). The fourteenth heir of these teachings was Tsongkhapa Lobzang Drakpa (Tib. tsong kha pa blo bzang grags pa, 1357-1419), who put the yogas of Nāropa in writing. ${ }^{5}$ The line of transmission based on hagiographies of above mentioned masters, is presented by Glenn H. Mullin in his translation of the teachings entitled The Practice of the Six Yogas of Näropa (further cited as Mullin, here Mullin 28.4/311). The six yogas of Nāropa apart from tummo - yoga of inner heat, bardo-yoga of intermediate state, phowa- yoga of transference of consciousness, includes also: gyulu (Tib. sgyu lus, Sanskr.: māhākāyāa)yoga of illusory body, ösel (Tib. 'od gsal, Sanskr.: prabhāsvara) - yoga of clear light, and finally milam (Tib. rmilam, Sanskr.: svapnadarśana) - yoga of the dream state. The last three, however, do not appear in the Taoist texts mentioned above. The choice of presenting the yogas of Nāropa and going backwards to their origins was deliberate. Firstly, because the six yogas of Nāropa are the first description of the well developed techniques as a system. Secondly, they represent two traditions that have to be taken into consideration: Indian and Tibetan. Both are discussed below.

\footnotetext{
${ }^{4}$ For detailed and specialised textual study on Six Yogas of Nāropa see Kragh.

${ }^{5}$ For history and line of transmission see Kragh 205.
} 


\section{EMERGENCY OR FORESIGHT - ANTE-MORTEM TECHNIQUES IN TAOISM AND TIBETAN BUDDHISM.}

According to the Taoist teachings the process of achieving immortality for internal alchemists is related to refinement of one's inner energies through mental and bodily practices such as gymnastics, breathing techniques, visualisation and mental concentration. As Eskildsen notices, when the inner spirit $^{6}$ of a practitioner is "conceived" and then adequately developed, it goes upwards from the abdomen to the head, from where it can get out of the body. The more advanced the adept, the bigger and self-reliant the inner spirit gets. At the beginning it cannot get very far from the body, but through the practice, the inner spirit literally grows so it becomes a "luminous replica of the adept's full-grown physical body" (Eskildsen 375). During the practice the inner spirit of an advanced adept should be able to come back to the body, and the inner spirit can develop into its fully mature form only through repeated excursions. When it happens at the moment of death the practitioner becomes a transcendent and should be able to perform miracles such as multi-location or clairvoyance. This part is not the actual antemortem meditation technique, but description of the internal alchemical process that enables the practitioner to let out his or her fully developed immortal inner spirit at the moment of death of the body.

The description of the process of sending the inner spirit in one of the texts is quite laconic. Zhen Longhu Jiuxian Jing states that a true transformation takes place when, in meditative concentration, the adept sends his/her inner spirit through his or her head forty-nine times (seven times seven) (Eskildsen 392-393). It reminds a phowa practice, not the final transference of the consciousness, but the process of preparing to it. The practitioner with the proper visualisation, through his central channel (which begins below the navel and goes along the spine, to top of the head its opening lays) should, having previously held breath, eject his or her consciousness through the opening of the central channel. At the moment of death ability to perform this technique guarantees liberation from cyclic existence. However, to be able to liberate oneself this way, one must previously master the technique by practising it regularly. After finishing each session, one must bring one's consciousness back to the central channel. If

\footnotetext{
${ }^{6}$ Eskildsen in his article capitalises the word Spirit to distinguish it from other kinds of spirits that appear in the Taoist tradition. He describes it as, "a singular, unified consciousness/life force, that survives and emerges from the flesh" (374).
} 
we perceive phowa practice not only as a one time meditation performed at the moment of death, but also as a repeated exercise to prepare oneself to the final moment of death, then phowa technically seems to be almost identical to the Taoist method of developing the inner spirit. The number of repetitions of the practice is also interesting here: seven times seven, because of its connection with bardo teachings, as traditionally 49 days is the time the consciousness stays in the intermediate state before being reborn.

The only question that remains is, if consciousness (Sanskr. vijñāna), which is translated into Chinese as shi 识, is comparable to the Taoist inner spirit.

Eslikdsen stated that the inner spirit can also be called for example the golden elixir (jindan 金丹) or, as Eskildsen translated this term, radiant spirit (yangshen 阳神) (374). Yang spirit and golden elixir are not always perceived as synonyms.

Golden elixir, especially in internal alchemy, is according to Fabrizio Pregadio something what a Buddhist would call the Buddha nature or the natural state of mind. This notion was expressed in this way by Chen Zhixu (1290-ca.1368), who claimed that golden elixir "is possessed by every human being, and is a representation of one's own innate realized state" (The Encyclopedia of Taoism 553, entry: jindan).

Yang spirit is defined as the most sublimed form of spirit completely cleansed of its yin aspect, so it can leave body at will (The Encyclopedia of Taoism 282, entry: chushen; 1081, entry: wuzhen pian, 3. neidan), and is stored in the crown of the head right before returning to the emptiness (The Encyclopedia of Taoism 777, entry: niwan). This description fits quite well the notion of inner spirit presented by Eskildsen. However, neither yang spirit nor the golden elixir is exactly the consciousness that is ejected through the crown chakra in the phowa practice. In spite of the fact that the Buddhist thought greatly influenced the later Taoist tradition of internal alchemy, the Taoist concept of human body remained unique and it is hard to expect to find a perfect match in "translating" one tradition into another. Nevertheless, the form, purpose and technique of both practices evince enough similarities to make them comparable.

In a scenario perfect for the internal alchemist he or she managed to develop his or her inner spirit enough to achieve immortality before the body wears away. If not and the moment of death comes or an adept's inner spirit cannot find its way back to the body during the practice, then it is the time to use practices described below. 


\section{ENTERING A WoMB (投胎 toutai)}

In the dictionary of modern Chinese, the entry toutai is defined simply as reincarnation, being reborn into a new body. The character tou means throw, drop, send or deliver and tai-foetus, embryo or birth, so according to the modern meaning of the characters, the term literally means to throw/drop/ send/deliver [into a new] embryo/birth.

Taibai huandan contains helpful instructions and descriptions for a practitioner in case his or her inner spirit got separated from the body and found itself in the intermediate state. The text describes the visions that the adept will experience, and suggests in what kind of form he or she is going to be reborn having yielded to a specific vision. For example the text mentions that "large houses are dragons" or "boats and carts are bugs and snakes," which according to Eskildsen means than if one is attracted by visions of large houses, one will be reborn as a dragon and if it is a vision of boats or carts, then one will become a bug or a snake (383). In that moment the most important task for the adept is to realise in what kind of situation he/she is, and to be able to control its outcome (383).

In Nāropa's instructions the only passage about visions one can experience in the bardo is very short. It says that when elements of the body dissolve, "The eighty conceptual minds are arrested and three visions pass" (Mullin 49/311).

Tilopa's version is more interesting in this case, because it mentions that at the time of death, Yogi should withdraw energies of the senses and elements, and concentrate, and as "consciousness goes to the outer objects" he should perceive them as a dream. Tilopa also advises meditating on Guru yoga, which will stop experiences of the bardo.

It is quite obvious that the techniques are similar: the main aim is to control one's mind in the intermediate state in order to influence the result of one's journey through it. The difference lies in emphasis on different aspects. Taoist text describes in details the visions of the intermediate state and the consequences of following them. Tibetan texts concentrate on instructions to focus one's mind to avoid being reborn in cyclic existence.

In the Chinese Taoist tradition not only Zhen Longhu Jiuxian Jing and Taibai Huandan Pian describe Taoist intermediate state. Eskildsen also presents more elaborate vision of the intermediate state that appear in much later text on internal alchemy Lingbao guikong jue 《灵宝归空诀》 ${ }^{7}$. This text

\footnotetext{
${ }^{7}$ The text was complied by Zhao Yizhen (赵宜真) who died in 1382. The title can be translated as The Verses on Lingbao Return to Emptiness
} 
gives precise instructions how to enter the intermediate state and to stay in control of it. ${ }^{8}$ In the commentary to this text Zhao Yizhen describes the process of dying. ${ }^{9}$ Both fragments sound similar to the content of so called Tibetan Book of the Dead - Bardo Tödrol Chenmo (Tib. Bar do thos grol chen mo $)^{10}$. Not only the practitioner is informed how the body dies (the order of dissolving elements and cessation of functioning of corresponding organs, its external symptoms and accompanying visions), but also is given instructions how to recognise these visions as illusions of bardo. These parallels are discussed in the most extensive way by Eskildsen (384-386).

\section{Changing Dwelling (移舍 yishe)}

Changing dwelling is a technique of possessing the "empty" body of a person who died. It is very superficially described in Taibai Huandan Pian without any details of the transition itself, but with the characteristic of a perfect "new dwelling". It would be the best, if it was the person that the adept knew, and of course, was already dead, preferably young boy, who hadn't been ill because of wind and cold (Eskildsen 395). This text does not mention the case of taking over the body of a living person, but in Zhen Longhu Jiuxian Jing there is a notice that such a misuse of this practice will be punished (Eskildsen 396). Taibai Huan Pian simply states that there is a possibility of changing the body for new one to continue adept's practice, but unfortunately does not give any instruction.

The technique of changing dwelling is very similar to the practice of forceful projection. In the Tilopa's instructions, yogas of consciousness transference and forceful projection are transmitted as one teaching. Nāropa however gives separate explanations to those two techniques. About forceful projection he teaches: "Especially, in the practice of forceful projection into another residence, Wherein one changes one's body like a snake shedding its skin, Take control of energies and mind, Make firm generation and completion stage yogas, and Throw consciousness in the form of mantric

\footnotetext{
${ }^{8}$ Zhao Yizhen suggests for example a bath in a hot peach water and change of clothes, as well as a cup of tea before returning to meditation. Later the author warns the adept against different visions that may appear and the adept should not get engaged in them, but rather remain focussed and unmoved. See Eskildsen 389.

${ }^{9}$ For example: "As your life is coming to an end, the eyes transform into nameless demons. The ears transform into Ashei demons. The tongue transforms into swift troops demons. The body transforms into demons of thought. (...)" (Eskildsen 390).

${ }^{10}$ More precise translation of this title is "Liberation Through Hearing During the Intermediate State" For more information see Cuevas.
} 
syllable into a corpse that is free from faults. For [both] these 'transference' methods the yogi must know well The time, place, substances required and principles involved" (Mullin 49/311).

The similarities between those two techniques are most striking. The method, aim and conditions are almost the same but again both texts concentrate on different aspects. In the Chinese text the emphasis is on the physical good condition of the "new dwelling", while Nāropa's focus evidently is on the stages of meditation. The explicit concern for moral consequences of such practice is mentioned only in Taoist texts.

This practice is extremely important from point of view of the history of Tibetan Buddhism, because it was a base of idea of so called Tulku (Tib. sptrul sku) ${ }^{11}$ system (Berounský, Part I). According to Daniel Berounský the practice of "entering residence" (Tib. grong 'jug) was also quite popular in India, where it was a very popular theme of Indian narratives (Part II 8). ${ }^{12}$ What seems to be quite interesting in this case is the fact that in Tibetan this ritual is called almost exactly the same as in Chinese while in Indian sources it was called "entering other body", "entering the other dead body", "entering other town", "entering the town of an enemy". Berounský explains that the Tibetan name of the ritual is in fact abbreviation, because originally it meant "entering fortified or walled residence/dwelling" (Part II 12-13). To be proficient in the time of need, the adept had to be advanced in the tummo practice and other yogas. He/she should also begin with visualisation before reanimating an actual corpse (Part II 16).

\section{Repelling the Killer Demons (拒杀鬼 $j u$ shagui)}

The last and the most interesting technique of prolonging one's life and eventually achieving the final realisation is called articulately "repelling killer demons". This is the only method that prolongs life of one's body without necessity of exchanging it for a new one. It can be used when one's inner spirit is almost mature and the adept needs only little more time to achieve his/her goal. Under the circumstances, when the adept feels the

${ }^{11}$ This term can be translated into Chinese as zugu 祖古, but in Mainland China much often the term huofo 活佛 is used. It means literally "living Buddha." It appeared in China in $16^{\text {th }}$ century. It was neutral in meaning and was widely used in China before 1949. Nowadays gained a pejorative meaning the Tulku system is controlled by Chinese government and every new "Living Buddha" must be approved by it.

${ }^{12}$ For more information about Indian narrative about entering dead bodies or exchanging bodies (Vetāla stories) see White. See also: Po-Chi Huang 211-235. 
looming death, he/she should visualise having an audience with the Realised-Ones, concentrate on inner being and block all the senses. Then with the heart, through concentration and holding one's breath, make the fire that will burn his/her body. The rest of visualisation reminds a battle with the armies of killer demons, which the adept should be not afraid of. As Eskildsen comments on the original text, through generating the inner fire, inner deities are activated and enabled to fight off the attack of killer demons. The body of the practitioner is visualised as a walled city with all the gates (sense organs) blocked. Even if the battle for the life of a body is won, demons may return, yet the inner spirit refined by combat is ready to achieve transcendence (Eskildsen 398-399).

This technique of making fire through visualisation and breathing exercises brings to mind the tummo practice. This esoteric practice, again, of the Indian provenance is practised by both Tibetan Buddhists and Bönpos. It may be one of the best known esoteric practices in the West, perhaps because its results are quite easy to measure, and can be scientifically proven. ${ }^{13}$

Inner heat yoga is the base of both Tilopa and Nāropa's teachings. According to Tilopa the practice should begin with gaining control over energy fields and channels of the body, and physical exercises. He mentions three channels (two side and one central). Flames arise from the place below the navel and life-sustaining nectar drops from the crown chakra (Mullin 43/311). Similar description of the meditation stages is given by Nāropa (ibid.).

In both Taoist and Buddhist practices generating inner heat prolongs practitioner's life. Both require a visualisation of practitioner's body in a certain way. And finally both bring the realisation of ultimate goal. In Taoist practice the heat is generated from the heart, but the commentaries on entering the womb practice in Zhen Longhu Jiuxian Jing say that apart from this practice there is another one that also refines the practitioner's body by burning it in inner transformative flames that arise from below and reach the head, while practitioner visualises that the heat fills all his or her body (Eskildsen 394). In Buddhist practice the inner heat arises from the base chakra. Also, inner alchemical description of the visualisation does not mention the nectar dropping from the HAM syllable on the crown chakra down the central channel. Tummo practice on the other hand does not require the

\footnotetext{
${ }^{13}$ The results of one of such studies were published in a popular science article "Meditation Changes Temperatures" written by William J. Cromie in Harvard Gazette on Arpil 18, 2002. This publication popularised even more the knowledge concerning Tibetan esoteric practices. The article is accessible online.
} 
visualisation of a battle with demons. The visualisation of a battle with demons however reminds strongly of the battle Buddha Sākyamuni fought against the armies of Mara right before achieving enlightenment.

Visualisation of one's body as a mountain or a walled city is quite frequent in Taoism. In consideration of the above mentioned Indian origins of the Tibetan ritual of "entering residence", imagining one's body as a fortress that one is guarding against killers may suggest that the Indian ritual was known to the Chinese and that the technique to repel intruders threatening their lives was developed on the basis thereof.

All three ante-mortem methods of meditation of internal alchemy tradition described by Eskildsen contain elements of the esoteric practices, such as visualisation and transformation, breathing meditation, blocking senses, with the purpose of developing inner awareness.

According to Tsongkhapa the tummo practice is the base of all yogas, because it depends on controlling vital energies and moving them into central channel, so mastering this technique is necessary to proceed with remaining five yogas (Mullin 18.7/311). Out of the six yogas of Nāropa the inner heat yoga, the illusory body yoga and the clear light yoga are the main practices that lead to enlightenment. The yoga of transference to a higher realm and into another body and bardo yoga are "only required if one fails to accomplish enlightenment before death grows near, and a forceful lastminute method of self protection is required" (Mullin 17.4/311).

Taoist techniques described in those two texts, are arranged together as a set of practices to be used when one fails to achieve the ultimate goal of his or her practice during lifetime. The technique of "repelling killer demons" seems to have a potential to be a practice that leads to the ultimate goal, just like tummo does. The text mentions that after the adept fights off the first attack of killer demons, they might come back and then he/she can leave the body and become a transcendent of some sort (Eskildsen 398). The "repelling killer demons" technique seems to be of a different nature that the remaining two. In commentaries to Zhen Longhu Jiuxian Jing this technique is described as "recalcitrant transformation" because its main point is to expel the inner destructive forces. In the other two practices the transformation is achieved "by accordance", which means that all the inner demons or destructive forces are transformed together with the practitioner without getting rid of them forcefully (Eskildsen 394). The texts or commentaries do not mention superiority or special importance of any of the practices. 
Even tough techniques and goals of both Taoist and Buddhist practices are very alike, the accents in the texts are placed differently. In teachings of Tilopa and Nāropa the instructions for the meditation and for the technique seem to be subject to the strongest emphasis. In Taoist texts a lot of place is devoted to description of experiences and outer conditions of the practice like for example physical shape of the body that is going to be used in practice of changing dwelling. It can be also noted that Taoist practices, as Eskildsen called them, are emergency techniques in case of premature (which means without attaining the ultimate goal) death, in Buddhism, however, even if used at the moment of premature death, they need to be foresightedly mastered earlier. Eskildsen also notices that Taoist meditations concentrate mainly on prolonging life and remaining in the body, while the focus of Tibetan yogas is elsewhere (Eskildsen 406).

\section{THE MISSING LINK — ON POSSIBLE SOURCES}

Despite of all the similarities mentioned above, and because of lack of a reliable written Tibetan source preceding composition of Six Yogas of Nāro$p a$ it is hard to find any other connections between these practices, and the biggest gap dividing them is that of several hundred years between appearance of these techniques. The first question that comes to mind is if they influenced each other at all or maybe they derived from the same old source and developped differently in different conditions. If not, what are other possibilities? They are discussed below.

\section{The TIMELINE PROBLEM WITH SIX YOGAS OF NĀROPA}

As it was mentioned earlier, according to the hagiographies of masters in the line of transmission of six yogas, the first written version of the practices should be that written down by Tsongkhapa as the fourteenth generation heir of the teachings. In accordance with A Book of three Inspirations by Tsongkhapa the order and the sources of these six practices are as follows: the most important and the base of all yogas is tummo, which was transmitted by Tilopa, who received it from mahāsiddha Krishnacharya and which has its sources in Hevajra Tantra and Heruka Chakrasamvara Tantra. Next are the illusory body yoga and the clear light yoga, which have their origins in oral traditions of Guhyasamaja Tantra. Last mentioned practice is phowa, that 
derived from Shri Chaturpita Tantra. The bardo yoga is not mentioned as it is considered a part of the illusory body doctrine (Mullin 29.7 -30.9/311).

The reason for mentioning all the sources is a problem with timeline. Taoist texts studied by Eskildsen are definitely earlier than Nāropa and even Tilopa and their doctrines. Also the Tantras, from which they are supposed to have been extracted, are dated from late $8^{\text {th }}$ to $9^{\text {th }}$ and $10^{\text {th }}$ century, so more or less to the same time as the Taoist texts, thus making the influence of Tantric Buddhism on Taoists texts rather impossible. It is worth to remember however, that many esoteric meditation techniques of Indian Yoga existed much earlier than Buddhism and were absorbed by it (Eliade 162273). So if they were an inspiration for Taoist practitioners, they were brought to China with Buddhism or there existed some alternative connection before Buddhism was brought through the Silk Road by merchant caravans.

The question of possible Indian influence on Chinese philosophy and meditation techniques is quite old. One of the most famous scholars who suggested this kind of relationship is Victor Mair. In the preface to his translation of Daodejing, he mentions relationship between Daodejing and Bhagavad-Gíta and finally he states that: "At present there are only three conceivable explanations for how this relationship could have developed: (1) China borrowed the Yogic system and its attendant practices from India; (2) India borrowed Taoism and its attendant practices from China; (3) both India and China were the recipients of inspiration from a third source" (Lao Tzu 19.7/260). Mair was not the first, who had this kind of idea. Eliade in his Yoga, Immoratlity and Freedom quotes Jean Filliozart, who undoubtedly had concluded that breathing meditation techniques must have been borrowed from India (Eliade 61). The text Eliade is referring to dates from 1949. The author could not have known about the manuscripts discovered in Mawangdui (马王堆) in 1973 or for example the scholarship on Inward Trining (內 业 nèiyè), a chapter of Guanzi (管子) that contains complete instructions to mystical techniques of inner cultivation through breathing mediation. It is dated to $4^{\text {th }}$ century $\mathrm{BC}$, which makes it older than the oldest preserved version of Daodejing (Roth 6, 26, 176). Is the Buddhist influence possible at all at that time?

Harold Roth analysed the stages of meditation in Inward Training and compared them with Hindu and Buddhist texts and concluded, that parallels are striking. Nevertheless, he also finds Mair's arguments on Indian influence and possible contact between India and China prior to the first 
commercial relations not persuasive. He finally states that these arguments suggest parallel developments "that occurred because of the application of similar method of psychophysical cultivation by human beings, who, despite their cultural differences were affected by these techniques in generally similar ways" (Roth 135-137). Of course similar "exercises" will have similar effects on human beings. Following detailed instructions of the inner heat yoga even non believer would attain some results. This is how, so popular nowadays, mindfulness techniques are used. So it is not the similar effect that seems to be astonishing, but way of developing techniques so much alike, yet based on different concepts of mystical physiology of human body. To actually perform all the discussed techniques the visualisation of central channel connecting base chakra with the crown of human skull is necessary. According to Livia Kohn, as early as mid-fourth century B.C.E. a notion of energetic pathway in the centre of the body leading from pelvic floor up to the top of the head appeared (Kohn 52). ${ }^{14}$ Deeper analyses of the origins of ideas concerning energy channels and other elements of invisible physiology, and how they correlate with development of specific techniques should help to find the answers, at least partially.

\section{YUnGDRUNG BÖN (Tib. g.yung-drung bon) TRADITION ${ }^{15}$}

It is a very tempting possibility to consider the role of pre-Buddhist Tibetan tradition, Bön (Tib. bon), in shaping techniques of ante-mortem Taoist mediations. Before introduction of Buddhism $\left(7^{\text {th }}\right.$ century $\left.\mathrm{CE}\right)$ it was a dominant religious tradition in Tibet. The form of those ancient practices is not known. Later, as Per Kvaerne explains, the original religion was superseded by Buddhism in $9^{\text {th }}$ century $\mathrm{CE}$ and reappeared around $11^{\text {th }}$ century $\mathrm{CE}$ sharing many similarities with Tibetan Buddhism. This is why term Bön is understood in different ways: as a primitive, shamanistic practice, as an organized religion resembling Tibetan Buddhism, that appeared in $11^{\text {th }}$

\footnotetext{
${ }^{14}$ For the illustration presenting energetic channels see Fig. 3.1 on Kohn 55.

${ }^{15}$ Yungdrung Bön means an Eternal, Unchanging Bon. gYung-drung is also a symbol in Sanskrit known as svāstika, which in Bon tradition is always turning counter clockwise. Sometimes Yungdrung Bön is simply called "Bon Buddhism." However, this term can be misleading, because if we understand Buddhism as a philosophy or religion that is based on the law of karma, that causes sentient beings to be reborn again and again in a cyclic existence, which can be avoided by recognition of the true nature of one's mind, achieved through practice of compassion and nonviolence, then, yes, we can call Yungdrung Bön - Buddhism. But if we define Buddhism as a doctrine that was founded by Buddha Śākyamuni, then Yungdrung Bön cannot be described as such.
} 
century (Yungdrung Bön), and as a collective term for popular beliefs, local deity cults and conceptions of soul with elements of primitive natural philosophy (Kvaerne 9-10). ${ }^{16}$ For the practitioners however, Yungdrung Bön has a history longer that 18.000 years and has been based on the law of cause and effect, love and compassion and self cultivating techniques to achieve enlightenment from the very beginning. ${ }^{17}$ Yungdrung Bön has its own canon, which includes many practices that are almost identical to those of other traditions of Tibetan Buddhism also all practices of the six yogas.

According to the hagiography of the legendary founder of Yungdrung Bön - Tonpa Shenrab (Tib. ston pa gShen rab), all the Bön practices have their source in his teachings, including the six yogas (Kvaerne 83-96). He himself was born in the land beyond our material world called Tagzig Olmo Lungring (Tib. rtags gzigs 'ol mo lung ring) ${ }^{18}$ over eighteen thousand years ago. Unfortunately most of religious texts of Yungdrung Bön are so called termas (Tib. gter ma) - "treasures" hidden because of persecutions by the Buddhists and "rediscovered" hundreds of years later often under mystical circumstances. The earliest Yungdrung Bön texts are dated to $11^{\text {th }}$ century, so until proven otherwise, Bön canon cannot be considered as a reliable source. ${ }^{19}$ As to practices included in the six yogas, they can be found in two Bön texts: $\mathrm{Mo}$ ther Tantra (Tib. Ma rgyud) and Zhangzhung Oral Transmission (Tib. Zhang zhung snyan rgyud). The second text is one of the few Bön texts that traditionally are not considered a terma, but unbroken line of oral transmission from the first teaching. The techniques presented in those texts are very similar to those of Nāropa so there is no need of describing them here again, also because the dating disqualifies them as reliable sources.

The only question that needs to be considered in this matter is fact that Bönpo priests, even after introduction of Buddhism into Tibet, were often responsible for funerary rites, which were very complicated and ritualised and strictly regulated in every detail (Kvaerne 3). Such level or ritualisation and specificity suggests a well developed belief system concerning death, dying and the afterlife, which of course does not automatically imply that

\footnotetext{
${ }^{16}$ For further history of Bon see Karmay 55-77.

${ }^{17}$ Yungdrung Bön include wide range of practices: from shamanistic to Dzogchen (Tib. rdzogs chen). They are divided into 9 ways. For further information see Snellgrove.

${ }^{18}$ Also transcribed as Olmo Lungring, for further information see Martin 99-120.

${ }^{19}$ Sometimes to validate pre-Buddhist origin of Bonpo practices that also can be found in Tibetan Buddhism the argument of appearance Zhangzhung language that supposed to be used before Tibetan script was developed and introduced. This question was discussed in the article by Blezer, Gurung, and Rath.
} 
near death meditation techniques were developed and used, but it is very likely. Especially, when analysing very different and complicated vision of the intermediate state presented in Bardo Thodol. Unfortunately, without the original Bön texts, one can only speculate.

\section{CONLUSION: "MADE IN CHINA"?}

The dating of particular texts or impossibility to find reliable sources excludes for the time being the Tibetan (Bön) influence on the Taoist techniques. Under these circumstances it is, in some sense, hard to disagree with Eskildsen, that it is a mixture of indigenous and Indo-Buddhist ideas. Buddhism, not only esoteric, but in all its forms that it took in China, undoubtedly had great influence on Chinese Taoism, especially on internal alchemy, but the fact is, that all the breathing techniques that are the basis for the Taoist ante-mortem meditations appeared earlier in China than introduction of Buddhism. So, as Roth argues, using similar breathing and concentration techniques could lead to a development of similar ideas. On the other hand, apart from the problem of some differences in the concept of mystical physiology of the human body that should influence visualisations, the vision of the afterworld in these Taoist practices suggests that this concept was newly developed or perhaps borrowed. During the Six Dynasties (liuchao 六朝, 220-589), before Tang Dynasty, a very elaborate idea of afterworld appeared. It was a mixture of pre-Buddhist Chinese concepts with those coming from India ${ }^{20}$. Both "ingredients" were quite complicated themselves, so such simple, or even one could say, vestigial vision presented in the Taoist texts is odd. And knowing the level of complexity of the visualisations of $q i$ circulation and of the inner deities meditations creating a complex visualisation of the afterworld wasn't an issue for an inner alchemist. For example bureaucratisation - one of the most important characteristic of the Chinese afterworld is invisible. ${ }^{21}$ The fact that the esoteric Buddhism was introduced in China in $8^{\text {th }}$ century (Chou Yi-liang 241-332), so more or less at the same time both the discussed Taoist scriptures were written, suggests

\footnotetext{
${ }^{20}$ For further information see Teiser.

${ }^{21}$ The Chinese afterworld was in fact the place, where dead person was judged and accordingly sent to another incarnation. It was often described as lasting seven weeks, at least the first stage, just like the Tibetan bardo. It was also transitional and not the destination itself. This is one of the reasons, why Teiser called it "a purgatory". It was often depicted as a bureaucratised place, where "souls" like petitioners, were standing in lines to get to the right officer.
} 
that Indian (Buddhist or not) esoteric notions must have reached China before that time or that they were in fact the indigenous invention.

Near death techniques of controlling one's mind and realising that visions are of illusory nature seem to be rather universal worldwide. Even in medieval Europe one can find scriptures on ars moriendi, that might be interpreted in a similar way. Advice for the dying person to withdraw his/her attention inward, concentrate on prayer without despair and agitation sounds very familiar to Buddhists, Taoists and Westerners. Ars moriendi ex variis scripturarum sententiis collecta ascribed to Mathew of Cracow (ca 13451410) contains descriptions of visions that the dying person could experience. They are connected with five diabolical temptations and yielding to any of them would influence person's situation after death (Trzy traktaty o sztuce umierania 19-25). Here again, I am not trying to make a detailed textual or linguistic comparison between Taoist texts and Ars Moriendi... To precisely confirm (or deny) supposed similarities a deeper and detailed analysis of the texts is necessary. Noticed parallels are just a result of a general look at the techniques themselves present in all texts.

Similarities across the cultures are possible and objectively speaking can be noticed quite often, especially when they concern events that are equal for every human being and involve some physiological process, just like death. This conclusion seem to be trivial, because if we only speak of a physiological process, it undoubtedly should be similar. But if we reverse Roth's reasoning, and can we assume that their religious concepts of a human body should be at least similar, based on the fact that different cultures can develop strikingly parallel techniques of inner cultivation or death preparation? Answering this question is not just a mere intellectual amusement. One can say that in the end does not matter which notion was first and which is just borrowed. It matters, however, if two (or maybe more) cultures independently develop techniques based on their own concepts of "mystical physiology" that still lead the same results.

\section{BIBLIOGRAPHY}

A Dictionary of Buddhism, edited by Damien Keown, Oxford University Press, 2003.

Berounský, Daniel. "Entering dead bodies and the miraculous power of the kings:The Landmark of Karma Pakshi's reincarnation in Tibet. Part I." Akademia, www.academia.edu/ 3453461/ Entering_dead_bodies_and_the_miraculous_power_of_the_Kings_The_landmark_of_Karma _Pakshis_reincarnation_in_Tibet_Part_I_. Accessed 6.03. 2020. 
Berounský, Daniel. "Entering dead bodies and the miraculous power of the kings:The Landmark of Karma Pakshi's reincarnation in Tibet. Part II." Mongolo-Tibetica Pragensia '11, Linguistics, Ethnolinguistics, Religion and Culture, vol. 4, no.2, 2011, pp. 7-29. Academia, www.academia.edu/3453475/Entering_dead_bodies_and_the_miraculous_power_of_the_Kings The_landmark_of_Karma_Pakshis_reincarnation_in_Tibet_Part_II_. Accessed 6.03. 2020.

Blezer, Hank, Kalzang Norbu Gurung, and Saraju Rath. "Where to Look For the Origins Zhang zhung-related Scripts?" Journal of the International Association for Bon Research, vol. 1, inaugural issue, 2013, pp. 99-127, himalaya.socanth.cam.ac.uk/collections/ journals/ jiabr/ pdf/JIABR_01_09.pdf. Accessed 3.05.2017.

Campany, Robert Ford. Making Transcendents. Ascetics and Social Memory in Early Medieval China. University of Hawaii Press, 2009.

Chou Yi-liang, "Tantrism in China." Harvard Journal of Asiatic Studies, vol. 8, no. 3/4, 1945, pp. 241-332, www.jstor.org/stable/i327661. Accessed 6.03. 2020.

Cromie, William J. "Meditation Changes Temperatures." Harvard Gazette, April 18 2002, news. harvard.edu/gazette/story/2002/04/meditation-changes-temperatures/. Accessed 3.05.2017.

Cuevas, Bryan J. The Hidden History of the Tibetan Book of the Dead. Oxford University Press, 2003.

Eliade, Mircea. Yoga, Immortality and Freedom. Translated from French by Willard R. Trusk, Routledge, New 1958.

Eskildsen, Stephen. "Emergency Death Meditations for Internal Alchemists." T'oung Pao. Second Series, vol. 92, fasc. 4/5, 2006, pp. 373-409, www.jstor.org/stable/4529048. Accessed 6.03.2020.

Karmay, Samten G. "A Historical Overview of the Bon Religion." Bon. The Magic Word. The Indigenous Religion of Tibet, edited Samten G. Karmay and Jeff Watt, Rubin Museum of Art \& Philip Wilson Publishers, 2007.

Kohn, Livia. Introducing Daoism. Journal of Buddhist Ethics Online Books, 2008.

Kragh, Ulrich Timme. Tibetan Yoga and Mysticism. A Textual Study of the Yogas of Nāropa and Mahāmudrā Meditation In the Medieval Tradition of Dags po. Studia Philologica Buddhica Monograph Series XXXII. The International Institute for Buddhist Studies, 2015.

Kvaerne, Per. Tibet Bon Religion: A Death Ritual of the Tibetan Bonpos. Brill, 1985.

Martin, Dan. "Olmo Lungring: A Holly Place Here and Beyond." Bon. The Magic Word. The Indigenous Religion of Tibet, edited Samten G. Karmay and Jeff Watt, Rubin Museum of Art \& Philip Wilson Publishers, 2007, pp. 99-123.

Lao Tzu. Tao Te Ching: The Classic Book of Integrity and the Way. Translation and afterword by Victor H. Mair, Bantam Books, 1990.

Po-Chi Huang. "The cult of Vetāla and Tantric Fantasy." Rethinking Ghosts in World Religions, edited by Mu-Chou Poo. Numen Book Series, Studies in the History of Religions, Vol. 123, Brill, 2009, pp. 211-235.

Roth, Harold David. Original Dao. Inward Training (Nei-yeh) and the Foundations of Taoist Mysticism. Columbia University Press, 1999.

Snellgrove, David L. The Nine Ways of Bon: Excerpts from Gzi-brjid. Oxford University Press, 1967. 
Sørensen, Henrik. "On Esoteric Buddhism in China: A Working Definition." Esoteric Buddhism and the Tantras in East Asia, edited by Charles D. Orzech, Henrik S. Sørensen, and Richard K. Payne, Brill, 2011.

Teiser, Stephen. The Scripture of Ten Kings and the Making Purgatory in Medieval Chinese Buddhism. University of Hawaii Press, 1994.

The Encyclopedia of Taoism, edited by Fabrizio Pregadio, Routledge, 2008, p. 553, entry: jindan by Fabrizio Pregadio; p. 282, entry: chushen by Maruyama Huroshi; p. 1081, entry: wuzhen pian, 3. neidan by Martina Darga; p. 777, entry: niwan by Monica Esposito.

The Practice of The Six Yogas of Nāropa. Translated and edited by Glenn H. Mullin, Snow Lion Publications, 2006, e-pub edition.

Trzy traktaty o sztuce umierania. Translated by Maciej Włodarski, Wydawnictwo Uniwersyetu Jagiellońskiego, 2015.

White, David Gordon. Sinister Yogis. University of Chicago Press, 2009.

\section{EZOTERYCZNY CHARAKTER PRZYGOTOWAŃ DO ŚMIERCI W TAOIZMIE I ICH MOŻLIWE ŹRÓDŁA}

Streszczenie

Stephen Eskildsen przeanalizował zbiór tekstów należących do taoistycznej tradycji wewnętrznej alchemii, zwracając szczególną uwagę na medytacje w obliczu śmierci. Biorąc wnioski Eskildsena za punkt wyjścia, głównym celem tego artykułu autorka uczyniła pokazanie podobieństw między technikami przygotowania do śmierci w taoizmie (,wejście do macicy”, „zmiana miejsca zamieszkania” i „odpychanie demonów zabójców”) a ezoterycznymi praktykami buddyzmu tybetański (The Six Yogas of Nāropa). Temat został wybrany po pierwsze dlatego, że niektóre z nich zostały pominięte przez Eskildsena, a po drugie dlatego, że podobieństwa te wydają się interesujące w kontekście ustalenia możliwych źródeł medytacji taoistycznych. Próba analizy źródeł obu zestawów praktyk i relacji między nimi prowadzi do wniosku, że wpływ ezoterycznych pomysłów indyjskich na chiński taoizm jest wysoce prawdopodobny. Autorka zauważyła również, że ćwiczenia oddechowe, które stanowią podstawę wszystkich omawianych technik, są wcześniejszymi wpływami buddyjskimi, a zatem możliwy jest również niezależny rozwój tych praktyk. Taki niezależny rozwój można uznać za interesujący, ponieważ zarówno techniki chińskie, jak i tybetańskie opierają się na podobnym pojęciu mistycznej fizjologii, co z kolei może sugerować pewien rodzaj uniwersalności.

Slowa kluczowe: praktyki ezoteryczne; wewnętrzna alchemia; techniki przygotowania do śmierci; stan pośredni; taoizm; Yungdrung Bön; Sześć Jog z Nāropy. 